\title{
Family Structure and Farm Organization in the Cotton Zone of Kita (Mali)
}

\author{
Adama Ouayiribe Traore, Breima Traore* \\ Department of General Economy, University of Social Sciences and Management, Bamako, Mali \\ Email address: \\ adamao_traore@yahoo.frs (A. O. Traore),breimat@gmail.com (B. Traore) \\ ${ }^{*}$ Corresponding authors
}

\section{To cite this article:}

Adama Ouayiribe Traore, Breima Traore. Family Structure and Farm Organization in the Cotton Zone of Kita (Mali). International Journal of Agricultural Economics. Vol. 5, No. 6, 2020, pp. 251-263. doi: 10.11648/j.ijae.20200506.14

Received: October 26, 2020; Accepted: November 5, 2020; Published: November 11, 2020

\begin{abstract}
This paper characterizes the structure of the family and family farms in the cotton zone of West Mali (Circle of Kita) using primary data from the survey of the Interuniversity Target Project (PIC) of the Mande Bukari University of Bamako (UMB), the Free University of Brussels (ULB) and the University Foundation Notre Dame de Paix de Namur (FUNDP). The study covered 211 households, with a study population of 3010 people in 18 villages surveyed, and the average family size was 11 people. The analysis of family structure shows that there are three types of families, namely the extended family, the mixed family and the nuclear family. This typology is strongly related to the organization of the farm. The results show that famsily breakups in the Kita area are moderate because most members of the concession live together in the same spatial unit under the authority of a main head of household. In addition, there are two types of family farms, collective and individual farms. The majority of collective plots $(86.43 \%)$ were inherited upon the death of the father or former head of the family. Land loan transactions are part of a traditional solidarity logic and not a land rental market as we know it in developed countries. The practice of individual farms is a growing phenomenon in the area, which have been granted by the head of the family to $96.89 \%$ of the members living in the concession, thus demonstrating the local character of the land loan market.
\end{abstract}

Keywords: Family Structure, Farming, Kita Circle

\section{Introduction}

Mali's economy is essentially, based on agriculture, which occupies a large part of the population. Depending on economic conditions, the rural development sector's share of GDP represents 36 to $40 \%$ at factor cost. Agriculture accounts for $65 \%$ of Mali's total population, or about 9.5 million people in 2009. This population growth is reflected in a rapid increase in the number of farms, especially in the cotton-growing areas, with a 2.8 and 2.6-fold increase since 1960 [3]. The growth dynamics in the cotton sub-sector have enabled small farmers to provide and improve their living conditions [29].

Indeed, family farming is the main form of organization of agriculture throughout the world. The relationship between family structure and farm organization is very important because it is family assets that provide the bulk of the world's agricultural labor force ( $40 \%$ of the world's population lives from agriculture, i.e. 2.6 billion people, including 1.3 billion working people) [2]. According to these, same authors, in Africa, family farms account for nearly $80 \%$ of farms with less than 2 hectares as average agricultural area and rudimentary equipment, mostly manual. Comparatively to commercial agriculture, family farms are based on much smaller areas of land [27]. This result was confirmed in Ghana by studies which in 1997 counted 800,000 family cocoa farms with an average area of 3 hectares per farm, of which $80 \%$ had less than 4 hectares [16]. In Benin, the average recorded size is 3.3 hectares [14].

In Mali, according to the General Census of Agriculture, the average population size in 2004 was 11 people and 1.7 households per farm [19]. The majority of farms (64\%) are of small demographic size with only one household; however, these farms account for only $43 \%$ of the agricultural population. The majority of the agricultural population (57\%) lives on farms with two or more households. Large families retain some importance with $8 \%$ of farms consisting of four or more households (i.e. more than 20 people), which 
account for $22 \%$ of the agricultural population. According to the same source, there are significant differences between regions: in the south (Sikasso region), there are large farms with 15 people and more than 2 households on average per farm; these differences decrease as one progresses northward (Kidal region) with six people and one household on average per farm. These differences between regions are linked to different modes of social organization but also, certainly, to a more rapid break-up of large families in the areas hardest hit by droughts, for example in the regions of Mopti and Ségou [3].

This overview of the farms shows that they are predominantly composed of nuclear households and highlights the crucial role of the family structure in the internal management of the farm. Thus, to understand the functioning of the units where production and consumption functions are concentrated, it is necessary to consider the level of the family farm and the lower levels (dependent households and individuals with individual activities) [21]. This implies an analysis of collective and individual family farms through a survey of the head of the farm or head of households and individuals with individual farms, respectively.

Indeed, the issue of farm management in Mali is becoming increasingly complex, especially in the old cotton basin of the Malian Textile Development Company (CMDT), where land pressure is very high because farmland is tired, demographics are galloping, and there is no more fallow land. More than 200,000 farming households with an average of 15 people per 10 ha carry out the cotton production in Mali [26]. In addition, the growing needs of young people (motorcycles, telephones, radio, etc.) in the cotton-growing areas are pushing them to seek individual farming and to become independent from the head of the family. This situation also leads people to migrate to other localities, particularly in the Kita circle in search of cultivable land.

This observation leads us to focus this work on the CMDT zone of Kita. It should be recalled that the Kita area is located in the former groundnut basin of Mali. The collapse of world groundnut prices in the early 1980s made groundnut production a poorly paid cash crop.

Since 1992, a Malian non-governmental organization (NGO) called SOS $\mathrm{KBK}^{1}$, which has experienced unprecedented growth, has introduced cotton cultivation in this locality. Following this spectacular result, in 1995, CMDT integrated the Kita region into its area of action by developing another cash crop: cotton. The Kita CMDT zone comprises four sectors: the central Kita sector, the Djidian, Kokofata and Sebekoro sectors. The interest in choosing this zone lies in the existence of situations worthy of interest in terms of changes in household management of land resources. In particular, there is land pressure in the area due to the presence of "turnips" and migratory flows from the cotton-growing area of southern Mali to conquer arable land. Hence the question of the impact of this rush by producers on

1 KBK designates Kita Bafoulabe and Keniéba family structure and the organization of farms in the Kita zone. Specifically, it is a question of trying to understand that with this wave of migration: what will be the new configuration of the family structure? How will the farms be organized?

To understand these concerns, the main objective of this study is to characterize the family structure and family farms in the Kita cotton zone. In particular, it is to explore:

1. The structure of the family, centered essentially on demography, family breakups, the turnip phenomenon, the migration issue;

2. Land, which mainly concerns collective and individual farms;

With regard to the objectives to be achieved, this work will be structured in four points. The first point deals with the review of the literature on the relationship between family structure and family farms, the second outlines the research methodology, the third point deals with the results and discussions and the last point concludes.

\section{Relationship Between Family Structure and Farms}

The rural economy consists in analyzing the economic phenomena in the rural space characterized by the predominance of agriculture. The latter is characterized by its social, economic, geographical, technical and organizational diversity [20]. The diversity of forms of agriculture reflects the extreme heterogeneity of economies and societies [2]. In Sub-Saharan Africa, these authors show that it is characterized by two main forms of exploitation, which are distinguished by the orientation of production (selfconsumption and market), technicality and the level of investment. These are the family farm and the entrepreneurial farm. However, there is a great diversity of family farms with high levels of investment and/or technicality. In addition to the types of family and entrepreneurial farms, employer farms that are characterized by a mixed workforce (family or salaried), capital with a family base (family or family association) and family and/or technical management [2].

All the actors highlighted the fundamental role of family dynamics in the evolution of production systems, from the work on the family organization of the peasant economy to the work that contributed to the International Year of the Family Farming in 2014 [24, 2, 7]. This renewed interest has prompted several countries to highlight the important role played by family farms in the socio-economic life of populations, especially rural populations. In fact, there are more than 570 million farms in the world, 500 million of which are family farms [8]. According to the 2006 census of the National Institute of Geography and Statistics, Brazil has 4,367,902 family farms out of 5,175,489 production units, or $84.4 \%[11,9]$. These farms use 80.25 million hectares $(24.3 \%$ of the total agricultural area) and employ three-quarters of Brazil's 12.3 million agricultural workers (74.4\%). They use 15.4 agricultural assets per 100 hectares 
and employ just over one million children and adolescents aged 14 and under, or $7.4 \%$ of total assets. This proportion falls to $3.6 \%$ in the case of entrepreneurial and entrepreneurial agriculture. The IBGE also notes that $90 \%$ of agricultural workers in family farming are related.

In Sub-Saharan Africa, most farms are family farms (nearly $80 \%$ ) and the sector employs nearly $75 \%$ of the active population [20]. This situation has led researchers to study the African family farm to facilitate intervention for agricultural and rural development [23]. Most of these studies have focused on the complexity of the family farm. Within each concession there is a primary and secondary operation [13]. For him, the farm is made up of a main decision-making center and several secondary decisionmaking centers: the main farm run by the head of the holding and the sub-farms run individually by each man or woman who depends on the head of the holding for food. In recent years, case studies of family farms in Brazil, Mali, South Africa etc. have been carried out by [1]. On the other hand, others have focused on all aspects of farm organization and operation [4]. For them, the family farm consists of a consumption unit and a production unit. The family farm is generally based on a diversified range of production including food and cash crops, livestock, fishing, forestry and other non-agricultural economic activities such as handicrafts, small trade, etc. [28]. The results on Benin reveal that farmers have oriented their production towards cash crops [30]. However, the production system still depends on cotton for access to fertilizers and other inputs for food crops.

The farmer or other members of his family see the pluriactivity of family farms as the carrying out of one or more activities, outside the farm work itself [17]. This pluriactivity is most often guided by necessity due to climate instability in the Sahel. Thus, a typology based on several variables (farm size, traction herd, extensive cattle herd and small ruminants), is proposed by [15]. Other authors use other criteria (socio-economic variables, agronomic variables and zoo technical variables) [22]. A typology according to material and equipment is made by [6]. On the other hand, a classification based on average area per asset is the result of [12]. In a study aimed at establishing the dynamics of smallholder farmers with regard to the integration of crop and livestock production in the CMDT zone in southern Mali, the authors conducted a classification of smallholders [29]. Studies have also shown the existence of certain key characteristics specific to the family farm, linked to the particular relationship between the structure and composition of the household and the agricultural assets and activities associated with it [26]. This relationship strongly influences the way decisions are made regarding the choice of crops, the organization of the family labor force and its allocation to different tasks, and the management of land and other agricultural assets [1]. Other studies have focused on the composition of the labor force [25].

\section{Methodology}

In order, to understand the family structure and the organization and management of family production units in the Kita cotton zone, the methodology consisted of a documentary review of existing studies and research work carried out by the technical services in charge of agricultural policies, and the economic, theoretical and empirical literature on the different themes addressed.

The collection of qualitative and qualitative data was carried out in October 2008, as part of a target interuniversity project (PIC) by the Free University of Brussels, the University Notre Dame de la Paix in Namur and the Mande Bukari University in Bamako.

The survey covered a sample of 211 randomly selected households spread over 18 villages in the Kita circle, chosen according to the CMDT's division into four sectors: Kita, Sebekoro, Kokofata and Djidjan. The villages were selected according to the weighting criteria relating to the size of the population in 14 communes. The communes are selected in the cotton production sectors according to the same weighting criterion, i.e.: 5 communes in Kita, 4 in Djidian, 2 in Sebekoro and 3 in Kokofata.

In addition to individual surveys, group interviews (village survey) were conducted. They were addressed mainly to the village authorities ${ }^{2}$.

STATA software was used to perform the analyses of univariate and bivariate descriptive statistics. The database contains information on demographics, concession assets, migration, farm organization, land management, crops (cotton, groundnuts, cereals, etc.), credit, etc. The database also contains information on the number of people living in the concession area, the number of people living in the concession area, and the number of people living in the concession area.

\section{Results and Discussion}

The results will focus on family structure, focusing mainly on demographics, family breakups, the turnip phenomenon, the migration issue, and on collective and individual farms.

\subsection{The Structure of the Family}

In family structure, we look at issues of demographics, family breakdown, turnip and laborer phenomenon and migration. Like the family types in the Koutiala CMDT zone, those in Kita have the same characteristics. In fact, family composition in the study zone is strongly linked to farm activity. There are generally three types of families in the study area:

a. Extended families where all members of the concession live together and work on the same collective farm under the authority of a single head of family;

2 Traditional village chief, administrative chief, councilors of the village chief, chief of land, other village notabilities, presidents and secretaries of village associations (VA) etc. 
b. Mixed families where, in addition to working on collective farms, some family members work on individual farms;

c. Nuclear families where the head of the family lives with his wives and unmarried children. They cultivate the same collective farms together. This last type of family is generally due to the independence of some members from the former head of the family.

Indeed, the traditional organization of the family provides that the head of the family lives with his wives, his younger married brothers and their descendants. Authority within these large families is in the hands of the head of the family following a strongly patriarchal tradition.

\subsubsection{Demographics}

The total population (Table 1) studied (12 years of age and older) in the sample is 3010 people: 1640 women $(54.49 \%)$ and 1370 men (45.51\%). Within this figure, 2350 people live in the concessions that is 1170 women $(49.79 \%)$ against 1180 men $(50.21 \%)$. On the other hand, it should be noted that 660 people (470 women and 190 men) live outside the concession. In the total population studied, women are the most numerous in terms of proportion, whereas if we look at the configuration of the total number of people living in the concession, men are the most numerous. These discrepancies are explained by the fact that women are the people who live the most outside the concession due certainly to marriages, especially early marriages of girls. The average family size for members who are at least 12 years old and living on the concession is 11.13 people, an average of 5.59 men and 5.54 women. This size is slightly larger than the sample in the Koutiala-Sikasso-San zone, which has an average family size of 10.43 [18].

Table 1. Number of Males and Females in Sample.

\begin{tabular}{lllll}
\hline Sex & Nb. of people living in the concession & Nb. of people living outside the concession & Total & Family Size \\
\hline Women & $1170(49.79 \%)$ & $470(71.21 \%)$ & $1640(54.49 \%)$ & 5.54 \\
Men & $1180(50.21 \%)$ & $190(28.79)$ & $1370(45.51 \%)$ & 5.59 \\
Total & $2350(100 \%)$ & $660(100 \%)$ & $3010(100 \%)$ & 11.13 \\
\hline
\end{tabular}

Source: Authors using data from PIC_October2008 survey, UMB-ULB-FUNDP in the CMDT area of Kita.

Analysis of the position of family members (Table 2) shows that the sons, daughters and wives of the head of the family are the most numerous, with respective proportions of $18.9 \%, 16.21 \%$ and $14.62 \%$ of the population studied.

Table 2. Position and Number of People Living Inside and Outside the Concession

\begin{tabular}{|c|c|c|c|c|}
\hline Position of members in the family & Nb. of people living outside the concession & $\%$ & Nb. of people living in the concession & $\%$ \\
\hline Head of family (HF) & 211 & 7 & 211 & 8.98 \\
\hline HF wives & 440 & 14.62 & 360 & 15.32 \\
\hline Son of the HF & 569 & 18.9 & 393 & 16.72 \\
\hline Daughters of the HF & 488 & 16.21 & 100 & 4.25 \\
\hline Milk brothers or sisters of the HF & 160 & 5.31 & 156 & 6.64 \\
\hline Sisters of Milk of the HF & 7 & 0.23 & 7 & 0.29 \\
\hline HF half-brothers & 67 & 2.22 & 65 & 2.76 \\
\hline Half-sisters of the HF & 18 & 0.6 & 17 & 0.72 \\
\hline FC daughters-in-law & 201 & 6.67 & 201 & 8.55 \\
\hline HF's sons-in-law & 2 & 0.06 & 2 & 0.02 \\
\hline HF's brothers-in-law & 9 & 0.30 & 9 & 0.38 \\
\hline Sisters-in-law of the HF & 277 & 9.20 & 275 & 11.70 \\
\hline HF nephews & 277 & 9.20 & 222 & 9.44 \\
\hline HF nieces & 63 & 2.09 & 62 & 2.64 \\
\hline Grandsons of the HF & 44 & 1.46 & 44 & 1.87 \\
\hline Granddaughters of the HF & 9 & 0.30 & 9 & 0.38 \\
\hline Parents of the HF & 121 & 4.02 & 120 & 5.10 \\
\hline HF Farm Laborers & 26 & 0.86 & 26 & 1.10 \\
\hline HF's little maid & 1 & 0.03 & 1 & 0.01 \\
\hline Foreigners & 2 & 0.06 & 2 & 0.02 \\
\hline Others & 68 & 2.26 & 68 & 2.89 \\
\hline Total & 3010 & 100 & 2350 & 100 \\
\hline
\end{tabular}

Source: Authors using data from PIC_October2008 survey, UMB-ULB-FUNDP in the CMDT area of Kita.

The largest age group in the study population (Figure 1) is over 18 years, of age with $79 \%$ followed by those between 12 and 18 years of age with $15 \%$ of the population and those under 12 years of age represent $6 \%$. The average age of a head of household in the sample is 57 , with a minimum of 20 and a maximum of 97 . 


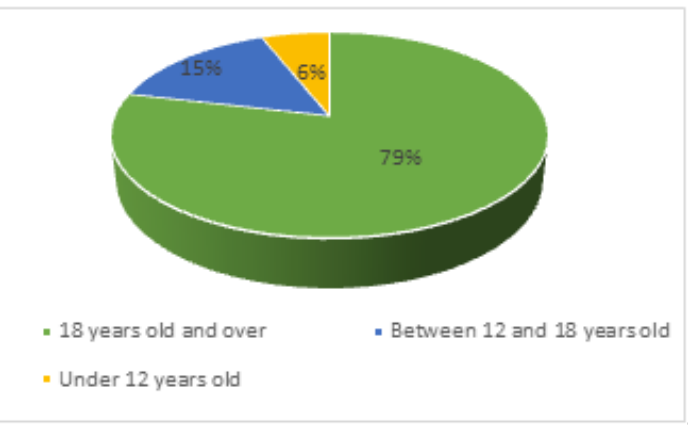

Figure 1. Proportion and frequency of different age groups of concession members

\subsubsection{Family Breakups}

According to the opinions of several interlocutors, during the community surveys, family breakups in the Kita area are moderate, i.e., in most cases, all members of the concession live together in the same spatial unit under the authority of a main head of household. Within this unit, however, each of the major members lives with his or her family and cultivates his or her own individual farm. The objective of this form of fragmentation is to force the members of the concession to devote themselves to their own farms in order to produce better. Usually, they may continue to eat their meals together at the home of the main head of the family. The main head plays an important role when there is a social event (baptism, wedding, funeral, conflict, etc.). Sometimes, becoming the head of the family within the family is done in a conflictual climate that pushes some members to become independent.

Becoming independent presupposes that the person benefiting from it is released from the obligations towards the former large family in terms of participation in the activities of the collective farm. He remains nevertheless subject to residual obligations such as financial contributions for social cases.

Notwithstanding, the types of breakdown mentioned above, analysis of the data (Table 3 ) reveals that the majority of the heads of households in the sample became heads of household after the death of the former (84.36\%). Only, $0.47 \%$ became heads of household following the former's disability or old age, (5.21\%) became heads of household following a move to independence, and $9.95 \%$ became heads of household otherwise.

Table 3. Ways in which the heads of families have gained access to the chiefdom

\begin{tabular}{lll}
\hline Ways to become a HF & Frequencies & Percentages \\
\hline Following the death of the former & 178 & 84.36 \\
As a result of disability or old age of the former & 1 & 0.47 \\
Following a move to independence & 11 & 5.21 \\
Become a HF otherwise & 21 & 9.95 \\
Total & 211 & 100 \\
\hline
\end{tabular}

Source: Authors using data from PIC_October2008 survey, UMB-ULBFUNDP in the CMDT area of Kita.

When we take the case of members who become the head of the family upon the death, disability or old age of the former HF (Table 4), the results show that in $91.62 \%$ of cases, family members continue to live together. Only $1.12 \%$ of HFs leave to create their own family and $5.03 \%$ withdraw to create their families when the new HF reaches this status. In view of the results obtained, we can no doubt conclude that in the families in the sample, there is not enough family breakdown after the death, disability or old age of the former HF.

Table 4. Family structure after the death, disability, or old age of the household head

\begin{tabular}{lll}
\hline $\begin{array}{l}\text { Family structure after the death, disability } \\
\text { or old age of the former HF }\end{array}$ & Frequencies & Percentages \\
\hline All family members continued to live together & 164 & 91.62 \\
The HF left to create his own family & 2 & 1.12 \\
Some members have become independent & 9 & 5.03 \\
Others & 4 & 2.23 \\
Total & 179 & 100 \\
\hline
\end{tabular}

Source: Author based on PIC October2008 survey data, UMB-ULBFUNDP in the CMDT area of Kita.

The results of the study show that there are multiple reasons why some dealership members become HF; these reasons are very much dependent on how they became HFs. In the case where the HF leaves to create his own family immediately after the death, disability or old age of the former HF, there are two reasons: one reason related to a family conflict and the other due to a decision by the eldest member of the family. It should be noted that $83.33 \%$ of cases are not applicable, i.e. cases where family members continue to live together on the concession. These results are mentioned in the table below.

Table 5. Reasons for becoming independent following the death, disability or old age of the former $\mathrm{HF}$

\begin{tabular}{lll}
\hline Reasons for the HF's independence & Frequencies & Percentages \\
\hline Family conflict & 1 & 8.33 \\
Elder brother's decision & 1 & 8.33 \\
Not applicable & 10 & 83.33 \\
Total & 12 & 100 \\
\hline
\end{tabular}

Source: Authors using data from PIC_October2008 survey, UMB-ULBFUNDP in the CMDT area of Kita.

In the situation where some members are withdrawing to create their own concession while a new HF gains this status (Table 6), four reasons are put forward:

a. There were too many of us in the dealership;

b. Simple independence;

c. Building my own family;

d. Because of the poor quality of the land.

These members often leave with their families $(28.57 \%)$ or with their milk brothers $(28.57 \%)$ or alone $(8.33 \%)$.

Table 6. Reasons for becoming independent at the time of the new HF

\begin{tabular}{lll}
\hline Reasons for the new HF's independence & Frequencies & Percentages \\
\hline Too many & 1 & 25 \\
Simple independence & 1 & 25 \\
Building my own family & 1 & 25 \\
The poor quality of the land & 1 & 25 \\
Total & 4 & 100 \\
\hline
\end{tabular}

Source: Authors using data from the PIC_October2008 survey, UMB-ULBFUNDP in the CMDT area of Kita. 
For those who became $\mathrm{HF}$ following a move to independence from the former HF (Table 7), the main reasons identified were among others:

a. Simple family separation without conflict;

b. Conflict in the family;

c. The family income is very low.

d. These and other no less important reasons are mentioned in the table below in relation to their respective frequencies and proportions. In the 21 cases in which people accessed the family leadership differently, the main reasons are explained by:

e. A conflict-free separation from the former HF (33.33\%);

f. The departure to the adventure of the former HF (23.81\%);

g. Too many responsibilities in the family (14.28\%).

For other no less important reasons, we note the forced departure of some members by decision of the HF, the emigration of some HFs etc.

Table 7. Reasons for independence at the time of the former HF.

\begin{tabular}{lll}
\hline $\begin{array}{l}\text { Reasons for the taking of independence at } \\
\text { the time of the former HF }\end{array}$ & Frequencies & Percentages \\
\hline Family income is very low & 2 & 13.33 \\
Family conflict & 2 & 13.33 \\
Separation without conflict & 4 & 26.67 \\
Earning my own money & 1 & 6.66 \\
Independence after marriage & 1 & 6.66 \\
Famine and individualism & 1 & 6.66 \\
Non-payment of wedding expenses by the HF & 1 & 6.66 \\
Not applicable & 3 & 20 \\
Total & 15 & 100 \\
\hline
\end{tabular}

Source: Authors using data from PIC_October2008 survey, UMB-ULBFUNDP in the CMDT area of Kita.

\subsubsection{The Phenomenon of "Turnips" and Maneuvering}

Before addressing this section, a distinction should be made between turnip and farm laborers.

A turnip is defined as a person officiating as a salaried labor force who occasionally stays in a reception area at specific times of the year. In the past decades, these turnips used to come to the Kita zone for groundnut cultivation but they gradually specialized in cotton cultivation. In recent years, most of the turnips come to the Kita area in search of land to cultivate. When they arrive at their destination, they look for a farm with a landlord who appears as a guardian and then settle down. The installation is done either in the landlord's family or elsewhere (village, hamlets...) to grow cotton, peanuts etc.... In many cases, they work 4 days a week in the landlord's farm and the other 3 days in their own farms. In many cases, they work 4 days a week in the landlord's farm and the other 3 days in their own farms, while the agricultural laborers go to a locality (or even live in the locality) for a given period of time (a month, a season, etc.) to provide agricultural services in return for a fee. They do not necessarily need to look for land to farm on their own.

According to the results of the study, only $6.63 \%$ of the families received turnip and laborers in 2008 compared to $14.22 \%$ in 2007 . In 2007 , the total number of turnips and laborers received by the families in the sample was 24 turnips and 13 laborers. The average per village is 1.33 turnip women. Among the villages, those whose respondents had the largest number of turnips were Linguema (5) located in the commune of Saboula-Balandougou and Banankoro (4) located in the commune of Kassaro. Half of the villages surveyed did not receive any turnips in 2007 . It should be noted that in recent years, the turnip phenomenon has decreased considerably in the Kita area because of the cotton crisis there. Today, the turnips no longer work much on the landlord's collective farms as they used to, they are more involved in their individual farms. They have indecent behaviors (detour of village women, theft of crops, negative influence on young people).

The majority of the turnips and laborers (Figure 2) come from the Koulikoro region (37.5\% turnips) and (46.15\% laborers), more precisely in the Banamba, Kolokani and Kangaba circles, then from the Kayes region, particularly the Kita circle, with $20.83 \%$ turnips and $38.46 \%$ laborers, and finally from the Sikasso region (Bougouni, Kouri, respectively $8.33 \%$ turnips and $7.49 \%$ laborers). This finding is contrary to our prediction and to a widely shared opinion in Mali, which assumed that the turnip growers would come from the Sikasso region, specifically Koutiala, where land pressure is very high. Regarding the proportion of turnip families, the results show that $63.33 \%$ of the turnip families lived in their landlords' concessions in 2007, compared to $46.67 \%$ in 2008 . This result is very plausible because the turnips, when they live in the concessions benefit from free housing and food. They often have an individual farm where they work 3 days a week and the rest of the time is devoted to the collective farms of the landlord. They may have agricultural inputs at the CMDT under the cover of the head of the family.

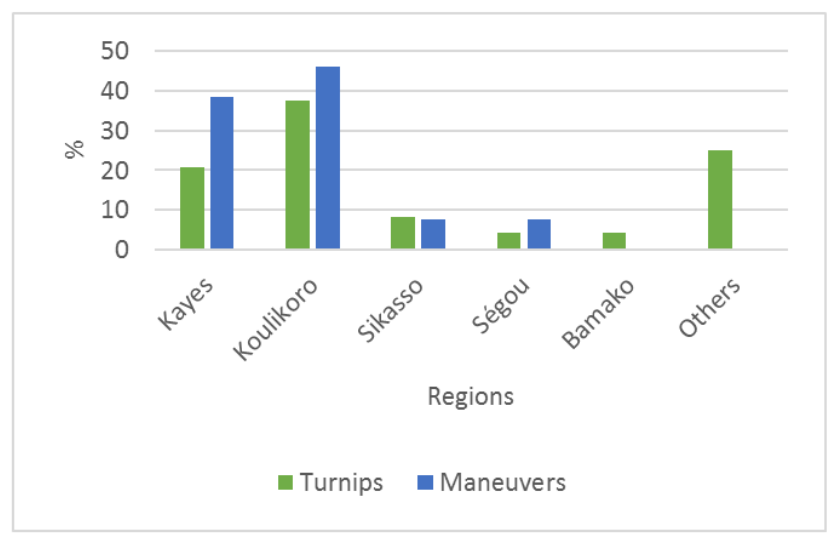

Figure 2. Origins of turnips and laborers.

\subsubsection{Migration}

The migration concerns urban and rural migration in Kita circle in 2007.

Rural Migration

In 2007, about 15 percent of families had sons who migrated to rural areas. In $56.25 \%$ of the cases, the head of the family makes the decision to migrate. According to the HFs surveyed, $40.63 \%$ of migrants made the decision to 
leave themselves. Among the reasons for rural migration, adventure is the main one with $46.63 \%$ and work with $25 \%$. However, during the community surveys, some heads of families mentioned others, namely:

a. When the agricultural season is bad, some heads of families send family members on temporary migration to other localities to seek additional income to make up the year's deficit;

b. When an (eldest) son is of marriageable age and the head of the family does not have the means to finance the marriage, he or one of his brothers is sent to another locality to work and get the money for the wedding.

In 2007, among the HFs of families with sons in rural migration, $50 \%$ stated that they had received migrants, gifts or money and $59.38 \%$ thought that these migrants would one day return to the village to take their place in their families. When the same HFs are asked whether these rural migrants will receive land at the time of division or inheritance, $96.88 \%$ respond affirmatively. $60.61 \%$ of the HFs think that these migrants will come to actually cultivate this land and $18.18 \%$ say they do not know.

\section{Urban Migration}

According to the results (Table 8$), 117$ sons $(20.56 \%$ of all HF sons in the sample) have migrated either to a town (Mali) or abroad (outside Mali). On average, $43.38 \%$ of the heads of households have a son in an urban area. Among the reasons given for urban migration are adventure (59.83\%), looking for work $(22.22 \%)$ and studies $(11.97 \%)$.

In relation to the decision to leave for urban migration, $64.96 \%$ of migrants say they made the decision on their own and $32.48 \%$ of decisions come from the head of the family.

In the Kita circle, adventure is the main cause of migration. The major concern of every head of family is to have at least one child outside, given the importance of the income that these migrants send them. The main destinations abroad are Spain (13.33\%), Libya and Gabon with $11.11 \%$ each.

In 2007, the total amount of transfers amounted to $4,870,000$ FCFA. The average transfer received by heads of families with at least one member migrating within Mali is estimated at $168,793.1$ FCFA. $15 \%$ of the heads of families received sums of between 300,000 and 750,000 FCFA. The largest transfers came from outside Mali, specifically from Spain (2,050,000 FCFA) and Gabon (1,200,000 FCFA).

When the heads of families were asked if they had ever been to the adventure, $65.88 \%$ answered affirmatively. This result shows that migration is not a new phenomenon in the Kita area. Most of these heads of families have lived in the past in Senegal, Côte d'Ivoire, Guinea Conakry, Gambia etc.. When asked if urban migrants will receive land at the time of division or inheritance, $88.89 \%$ of the heads of families say yes, however $44.44 \%$ of them say they will not come to cultivate it against $28.21 \%$ who think the opposite and $20.21 \%$ say they do not know. Men leave the concession at an average age of 19.82 years and women at 15.69 years. The age at which women leave the concession is not surprising since most leave very early for marriage.
Table 8. Location of Urban Migration in 2007 (Frequency, Proportions, and Transfers).

\begin{tabular}{llll}
\hline $\begin{array}{l}\text { Location urban } \\
\text { migration }\end{array}$ & Frequencies & $\%$ & $\begin{array}{l}\text { Amounts of FCFA } \\
\text { transfers }\end{array}$ \\
\hline Bamako & 11 & 12.22 & 240000 \\
Kayes & 17 & 18.88 & 200000 \\
Ségou & 1 & 1.11 & 100000 \\
Niono & 1 & 1.11 & 0 \\
Kita & 9 & 10 & 75000 \\
Cameroon & 1 & 1.11 & 0 \\
Ivory Coast & 1 & 1.11 & 0 \\
Senegal & 3 & 3.33 & 135000 \\
Spain & 12 & 13.33 & 1200000 \\
Gabon & 10 & 11.11 & 2050000 \\
Italy & 2 & 2.22 & 300000 \\
Libya & 10 & 11.11 & 490000 \\
Mauritania & 2 & 2.22 & 80000 \\
Djenekotra & 1 & 1.11 & 0 \\
Unknown & 9 & 10 & - \\
Not applicable & 27 & 23.07 & - \\
Total & 117 & 100 & 4870000 \\
\hline
\end{tabular}

Source: Authors using data from PIC October2008 survey, UMB-ULBFUNDP in the CMDT area of Kita.

\subsection{Analysis of Collective and Individual Farms}

According to the Kita Circle Council, this locality is a special area, as it covers an area of $35,250 \mathrm{~km}^{2}$ or $3,525,000$ ha, of which 738,000 ha $(21 \%)$ is arable land. This figure represents $24 \%$ of the arable land in the Kayes region and thus places Kita in first position. The potential for hydroagricultural development represents 14,575 ha $\left(\mathrm{DRGR}^{3}\right.$ Kayes) on which 11,075 ha of plains, 206 ha of ponds and 3,294 ha of shallows. This potential means that land conflicts are relatively rare in rural areas.

According to the information document of the Kita Integrated Rural Development Project (PDRIK), the average cultivated area per capita is low ( $0.37 \mathrm{ha})$ and attests to the lack of agricultural equipment. In comparison, the norm for southern Mali is 0.63 ha, with peaks of 0.80 ha in the old cotton basin (Koutiala, Fana). This norm is reached in some areas of Kita, the best equipped, notably in the former district of Kokofata ( 0.81 ha in Kokofata, 0.84 ha in Tambaga). The average population density is 10 inhabitants per $\mathrm{Km}^{2}$. Let us now analyze the situation of the practice of collective and individual farms.

\subsubsection{Collective Farms}

According to the study's definition, collective farms are plots of land owned by the entire family where all members of the concession work under the authority of the head of the family. The income or crops from these farms are invested or consumed within the family. In the Kita zone, there are three main types of collective plots, namely collective plots of cotton, groundnuts and cereals (millet, sorghum, maize, etc.).

In 2007, the total area of plots collectively (Table 9) cultivated by families was 964.5 ha, or an average area per village of 53.58 ha. More than half of these villages have an area below the average. However, the largest area is 92.25 ha

\footnotetext{
3 Regional Direction of Rural Engineering of Kayes
} 
$(9.56 \%)$ in the village of Massala in the commune of Kita-Est and the smallest area is 31 ha in Badougou in the commune of Toukoto.

Table 9. Areas per village of collectively cultivated plots (PCs) in 2007.

\begin{tabular}{lll}
\hline Villages & Surface area (ha) & Percentages \\
\hline Fodebougou & 80.5 & 8.34 \\
Massala & 92.25 & 9.56 \\
Golobiladji & 71.5 & 7.41 \\
Dougna & 41.5 & 4.30 \\
Bayala & 72 & 7.50 \\
Kotedo & 37.5 & 3.88 \\
Konitonoma & 49 & 5.08 \\
Bambala & 56.25 & 5.83 \\
Tofassadala & 61.5 & 6.37 \\
Banankoro & 59 & 6.11 \\
Kokolon & 44.25 & 4.58 \\
Nantela & 50.25 & 5.20 \\
Diagala & 60.5 & 6.27 \\
Tagabarissan & 32 & 3.31 \\
Bagalinta & 31.5 & 3.26 \\
Kourougué & 51 & 5.28 \\
Linguema & 43 & 4.45 \\
Badougou & 31 & 3.21 \\
Total & 964.5 & 100 \\
\hline
\end{tabular}

Source: Authors using data from PIC October2008 survey, UMB-ULBFUNDP in the CMDT area of Kita.

Figure 3 shows that $86.43 \%$ of the collective plots were received as inheritance upon the death of the father or the former head of the family; $4.77 \%$ of the plots were received as loans; $4.77 \%$ of the plots were cleared by the new head of the family not coming from the former head of the family. Of these collective plots, $94.97 \%$ are owned by the head of the family; $4.77 \%$ are owned by another farmer in the village and $0.25 \%$ are owned by a family member living in the village. In terms of the quality of these collective plots, $93.97 \%$ of the plots are rained land, $5 \%$ are lowland and $0.75 \%$ are orchards.

The number of collective plots per household is 1.88 . This number is very low and shows the decrease in the practice of collective plots in favor of individual plots. Of the 398 collective plots, 231 of them have part of their area loaned to a member of the concession as individual plots and part of the 25 collective plots are loaned to another farmer in the village as individual plots.

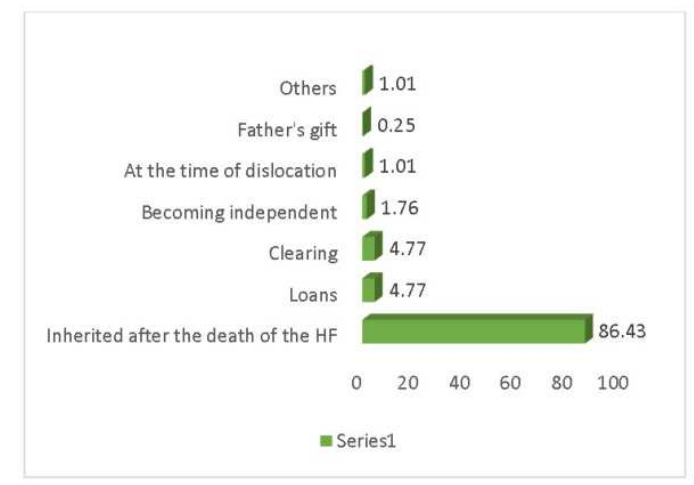

Figure 3. Method of acquisition of collective plots cultivated in wintertime.
When we asked the heads of households about land conflicts on collective plots (Table 10), 97.49\% stated that they had not experienced any land conflicts; only $1.51 \%$ had experienced any plot claims. However, land conflicts are more frequent in the town of Kita and its suburbs. These conflicts generally relate to plots for residential use.

These results are almost identical to those of Koutiala, where $98.45 \%$ of HFs say they have not experienced land conflicts [18]. However, during community surveys in some villages, such as in Bagalinta and Bayala in the communes of Sagabary and Sirakoro respectively, the populations reported intermittent conflicts between the Fulani who come with their herds of cattle from Nara and Nioro or from the border with Mauritania to settle in their bush during the winter months. Once settled, these Fulani cut down all kinds of trees to feed the animals, and often their animals return to the farmers' plots.

When asked whether the 211 heads of household in the sample had to resort to an outside authority (town hall, court, land or village chief) to resolve a land dispute, the results show that there were no cases of recourse to the town hall or the court. However, there were 6 cases of recourse to the chief of land or the village chief. The circumstances of these six cases of conflict mentioned are as follows:

a. -I had lent a plot of land to a peasant who did not want to give it back to me;

b. -My brother-in-law had cultivated my land without consulting me;

c. -A foreigner settles on my land without my authorization;

d. -Invasion of my land by other people's animals (animal raving);

e. -The owner of my plot wanted to take his plot away from me before the harvest;

f. -My half-brother wanted to reduce the size of our plot by taking over part of it.

These results remain very low compared to those in the Koutiala-Sikasso-San study zone, where out of the 301 heads of household interviewed on the issue, 11; 13 and 39 heads of household appealed to the mayor's office, the court, and the chief of land or the village chief respectively [18].

Another way of dealing with the issue of land conflicts was to ask the heads of families whether or not they would accept the land title if it was offered to them. Before answering this question, $47.87 \%$ of the heads of families stated that they did not know the meaning of land title. After explanation of the concept of land title, $94.31 \%$ of heads of families said they would accept the land title, compared to $5.69 \%$. The supporters of land title give two reasons:

a. The land title is a lifetime guarantee of the land for us and for our future generations (children, grandsons etc.) $(95 \%)$;

b. The title allows avoiding and reducing land conflicts $(5 \%)$ especially after the death of the current owner.

c. For those who refuse to accept the land title, they give the following reasons:

d. With the land title, the rich will buy all our land; 
e. The earth belongs to no one, it belongs to God, therefore one should never look for a paper to have it;

f. The practice of land title is forbidden by our customs, our ancestors never did it;

g. Land title is a source of conflict.

Table 10. Types of conflicts encountered in collective plots.

\begin{tabular}{lll}
\hline Types of conflicts & Frequencies & Percentages \\
\hline Limit & 1 & 0.25 \\
Claiming parcels & 6 & 1.51 \\
Animal Divagation & 3 & 0.75 \\
No conflicts & 388 & 97.49 \\
Total & 398 & 100 \\
\hline
\end{tabular}

Source: Authors using data from the PIC_October2008 survey, UMB-ULBFUNDP in the CMDT area of Kita.

An analysis of the modes of acquisition and disposal of the different types of plots (Table 11) reveals that there were 30 collective plots that were the subject of land transactions. Among these plots, there were 15 acquisitions including 12 collective plots that did not belong to the HF but were obtained elsewhere, and 3 plots recovered by the HF and that had been lent by him or his parents. There were also 15 cases of transfer, including 10 plots loaned by the family $\mathrm{HF}$ to another farmer in the village and 5 plots given as gifts to his children or another person. These results clearly show that land loans follow a traditional logic and do not really meet the definition of land lease transactions as understood in developed countries. More specifically, land loans are part of personalized and inter-generational relationships based on the idea of exchange of services and mutual aid over a long period of time. These results were confirmed for Burkina Faso, as well as for Niger [5, 10].

On the other hand, in the same study area, there were no cases of plots bought or exchanged, nor sold, nor were there any cases of pawn taking or pledging. Regarding sales, some respondents claim that there are attempts to sell or sales of land in some villages near Kita and in the peri-urban area of Kita, but no one dares to report them. In the cotton zone of Koutiala, two cases of land sales are shown in the results and 63 transactions [18]. However, the survey results showed the creation of a land market in the peri-urban area of Koutiala. In the San zone, land pledges are common.

As in the Koutiala study area, land transactions in the Kita study area are still very low. This observation is reasonable insofar as there is still more land available in the Kita zone and land pressure is less than in the old cotton basin of Koutiala.

Table 11. Other Types of Land Transactions in the Study Area.

\begin{tabular}{lll}
\hline Types of plots & Frequencies & $\begin{array}{l}\text { Average } \\
\text { surface area }\end{array}$ \\
\hline Collective parcels not belonging to the HF & 12 & 19.66 \\
Plots lent by the HF to a farmer not & 10 & 6.57 \\
residing in the concession & 3 & 1.17 \\
Plots recovered by the HF & 5 & 3.6 \\
HF gift to a child or another person & 0 & 0 \\
Collective plots bought or exchanged & 0 & 0 \\
Plots sold & 0 & 0 \\
Pledged plots & & \\
\hline
\end{tabular}

\begin{tabular}{lll}
\hline Types of plots & Frequencies & $\begin{array}{l}\text { Average } \\
\text { surface area }\end{array}$ \\
\hline Pledged plots & 0 & 0 \\
Total & 30 & 31 \\
\hline
\end{tabular}

Source: Authors using data from PIC_October2008 survey, UMB-ULBFUNDP in the CMDT area of Kita.

\subsubsection{Individual Farms}

Individual farms are usually plots of land that some family members cultivate to generate their own income. These individual plots are either granted to family members by the head of the family or obtained elsewhere from another farmer in the village. They are a source of additional income for members who have access to them.

In the Kita area, the phenomenon of individual plots of land has now become common practice. Out of a population of 1191 people who have individual plots, the heads of families report having granted plots to 1154 members living in the concession either $(96.89 \%)$ and only 37 family members have obtained plots elsewhere in the village either $(3.10 \%)$. This shows that the majority of these individual plots of land belonging to members of the concession are donated by the HFs, and the HFs own $94.27 \%$ of them. These results thus show the local character of the loan market (Table 12).

The increase in the use of individual plots is explained by the availability of arable land $(738,000$ ha). As many peasants pointed out during the community surveys, the multiplication of individual plots is a strategy to encourage all members of the concession, especially the "stowaways", to work more.

In the sample, the proportion of women operating an individual plot is higher than that of men, $67 \%$ of women versus $33 \%$ of men. Among the family members who own many of the individual plots, HF wives come first with $25.78 \%$, followed by sisters-in-law $(17.50 \%)$, daughters-inlaw (13.94\%) and sons (11\%).

Clearly, all the figures point to the conclusion that women own more individual plots than men. This is obvious, when one considers that women pose less of a threat to the head of the family's land portfolio than men, it is easier for a woman than a man to later withdraw a granted plot of land. As a result, heads of households are more likely to grant individual plots to women. In addition, opportunities for women to withdraw plots are likely to occur upon the death of the husband, marriage, repudiation, divorce, and so on.

As in Koutiala, the heads of families prefer to give more individual plots to women and children, because the income from collective plots is insufficient to meet the increasing new needs of the concession members. The resources generated by the women's individual plots go a long way toward covering the families' current expenses (condiment costs, oil, etc.). They support the men during the lean season.

Among the men of the family, the sons of the head of the family are the most numerous to have individual plots of land, the income from these plots allows them to meet their additional needs (motorcycle, cell phone, radio, weddings 
etc.).

When family heads are asked if they find it normal for their family members to obtain elsewhere from other owners of individual plots without consulting them. $91.37 \%$ of the heads of families think that this is abnormal because this attitude is a lack of respect for the chief and leads to land conflicts and even family breakups. Similarly, $51.78 \%$ of heads of families said that the fact that some family members have individual plots of land can cause family breakups and ultimately constitutes a risk of abandoning collective plots of land in favor of individual plots of land. When asked whether the head of the family will ever recover the individual plots of land granted to family members, $54.87 \%$ of the heads of households said that they will not recover them. On the other hand, $64.49 \%$ of the heads of families said that family members will not inherit these individual plots.

Table 12. People living in the concession who own individual plots of land (IPs) granted by FC or obtained elsewhere.

\begin{tabular}{|c|c|c|c|c|}
\hline Types of people & Nb. of people who obtained plots with the HF & Nb. of people who obtained plots elsewhere & Total & $\%$ \\
\hline Head of Family (HF) & 37 & 2 & 39 & 3.27 \\
\hline Wives of the HF & 299 & 8 & 307 & 25.78 \\
\hline Son of the HF & 126 & 5 & 131 & 11 \\
\hline Daughters of the HF & 8 & 0 & 8 & 0.69 \\
\hline Brothers or sisters of the HF & 86 & 2 & 88 & 7.39 \\
\hline Half brother or sister of the HF & 29 & 4 & 33 & 2.77 \\
\hline HF daughters-in-law & 166 & 0 & 166 & 13.94 \\
\hline HF's brothers-in-law & 1 & 0 & 1 & 0.08 \\
\hline Sisters-in-law of the HF & 200 & 12 & 212 & 17.80 \\
\hline HF nephews & 68 & 1 & 69 & 5.79 \\
\hline HF nieces & 5 & 0 & 5 & 0.42 \\
\hline Grandsons of the HF & 4 & 0 & 4 & 0.33 \\
\hline Granddaughters of the HF & 0 & 0 & 0 & 0 \\
\hline Parents of the HF & 66 & 2 & 68 & 5.71 \\
\hline HF farm laborer & 20 & 1 & 21 & 1.76 \\
\hline Foreigners & 0 & 0 & 0 & 0 \\
\hline Others & 37 & 0 & 37 & 3.11 \\
\hline Total & 1154 & 37 & 1191 & 100 \\
\hline
\end{tabular}

Source: Authors using data from PIC_October2008 survey, UMB-ULB-FUNDP in the CMDT area of Kita.

In 2007 , the total area of individual plots of land was 121.63 ha with an average of 6.75 ha per village. More than half of the villages surveyed had above average areas. Tagabarissan (10.25 ha) and Bambala (10 ha) have the largest areas, while the smallest area is in Nantela (1.56 ha) in the commune of Kobri. (Table 13).

Table 13. Areas per village of individual plots cultivated in 2007.

\begin{tabular}{lll}
\hline Villages & Surface area (ha) & Percentages \\
\hline Fodebougou & 7.75 & 6.37 \\
Massala & 9 & 7.40 \\
Golobiladji & 6.5 & 5.34 \\
Dougna & 8.26 & 6.79 \\
Bayala & 2.31 & 1.90 \\
Kotedo & 4.5 & 3.70 \\
Konitonoma & 9 & 7.40 \\
Bambala & 10 & 8.22 \\
Tofassadala & 8 & 6.58 \\
Banankoro & 5 & 4.11 \\
Kokolon & 3.5 & 2.88 \\
Nantela & 1.56 & 1.28 \\
Diagala & 9 & 7.40 \\
Tagabarissan & 10.25 & 8.42 \\
Bagalinta & 5 & 4.11 \\
Kourougué & 5 & 4.11 \\
Linguema & 8.5 & 6.98 \\
Badougou & 8.5 & 6.98 \\
Total & 121.63 & 100 \\
\hline
\end{tabular}

Source: Authors using data from PIC_October2008 survey, UMB-ULBFUNDP in the CMDT area of Kita.
In Table 14, the average size of the individual plots of the men who live in the concession and sell part of their crops is 0.71 ha. This is greater than the women's plot size of 0.62 ha. The total number of individual plots of men who sell part of their crops and live in the concession (417 individual plots or $51.54 \%$ ) is greater than that of women (392 individual plots or $48.45 \%$ ). This result is plausible because women, even though they sell their crops, devote a large part of them to family consumption. While men, especially young men, have new and growing needs (telephones, motorcycles, radio, etc.).

Of the concession members who have individual plots, sons and grandsons have the largest average area (0.79 ha). This is normal because they are the ones who express more needs and are the able-bodied arms of the family. These results are significantly lower than those of the CMDT zones in southern Mali, with Sikasso (1.68 ha for women and 3.04 ha for men) and Koutiala ( 0.94 ha for women and 0.88 ha for men) but higher than those of San ( 0.56 ha for women and 0.68 ha for men) [18].

Table 14. Average size of individual plots of the family members who live in the concession and sell part of their harvest.

\begin{tabular}{llll}
\hline Types of people & $\begin{array}{l}\text { Average } \\
\text { surface area }\end{array}$ & Comments & \% \\
\hline Head of Family (HF) & 0.71 & 73 & 9.02 \\
Wives of the HF & 0.64 & 114 & 14.09 \\
Son of the HF & 0.79 & 129 & 15.94 \\
Daughters of the HF & 0.76 & 30 & 3.71 \\
\hline
\end{tabular}




\begin{tabular}{llll}
\hline Brothers or sisters of the HF & 0.71 & 69 & 8.53 \\
Half brother or sister of the HF & 0.76 & 31 & 3.83 \\
HF daughters-in-law & 0.55 & 54 & 6.67 \\
HF's sons-in-law & 0 & 0 & 0 \\
HF's brothers-in-law & 0.56 & 7 & 0.87 \\
Sisters-in-law of the HF & 0.62 & 121 & 14.96 \\
HF nephews & 0.60 & 82 & 10.14 \\
HF nieces & 0.64 & 25 & 3.08 \\
Grandsons of the HF & 0.79 & 17 & 2.10 \\
Granddaughters of the HF & 0.44 & 4 & 0.49 \\
Parents of the HF & 0.52 & 38 & 4.70 \\
HF farm laborer & 0.5 & 5 & 0.62 \\
HF's little maid & 0 & 0 & 0 \\
Foreigners & 0 & 0 & 0 \\
Others & 0.77 & 10 & 1.24 \\
Total & 11.3 & 809 & 100 \\
\hline
\end{tabular}

Source: Authors using data from PIC_October2008 survey, UMB-ULBFUNDP in the CMDT area of Kita.

Concerning the rules of work on individual plots, they vary according to the locality and the position of the members in the family. In Table 15, the results show that depending on the locality, Fridays and Mondays are public holidays for work on collective plots, therefore, the owners of individual plots work on these holidays in their plots. On other days (13.62\%) of (young) people usually cultivate their individual plots, in the morning before the work on the collective plots and in the evening after the descent; $31.70 \%$ of people cultivate their individual plots only in the evenings. In cases where the person cultivates his individual plot when he wants to, we note $(12.66 \%)$ people or every day of the week $(22.83 \%)$. Most of these people are men and women, generally very old, who no longer work on the collective plots. For those who cultivate their individual plots after household chores, we note $(4.62 \%)$, it is active women who, after household chores, work on these types of plots.

Table 15. Work rules in the individual plots of the members living in the concessions

\begin{tabular}{lll}
\hline Work rules & Frequencies & Percentages \\
\hline When he/she wants & 137 & 12.66 \\
$\begin{array}{l}\text { After household chores } \\
\text { Mornings and evenings after the work of the } \\
\text { collective plot of land }\end{array}$ & 50 & 4.46 \\
$\begin{array}{l}\text { On a day chosen for the individual plot of } \\
\text { land }\end{array}$ & 149 & 13.77 \\
$\begin{array}{l}\text { Every day of the week } \\
\text { Every morning }\end{array}$ & 247 & 0.09 \\
$\begin{array}{l}\text { Every night } \\
\text { Others }\end{array}$ & 75 & 22.83 \\
Don't know & 343 & 6.93 \\
Total & 68 & 31.70 \\
\hline
\end{tabular}

Source: Authors using data from PIC_October2008 survey, UMB-ULBFUNDP in the CMDT area of Kita.

A review of the 2007 data shows that the turnip phenomenon has decreased significantly in the Study Area. Only 24 turnips were found in the sample, each with an average area of 0.95 ha. This area is higher than that of the men $(0.71 \mathrm{ha})$ and women $(0.62 \mathrm{ha})$ living in the concession. Regarding the working rules for turnip growers, the rule of "three working days in the week" is the most common with $46 \%$ (Figure 4). That is to say that the turnip girls work 3 days in their individual plots and work the rest of the 4 days of the week in the landlord's plot.

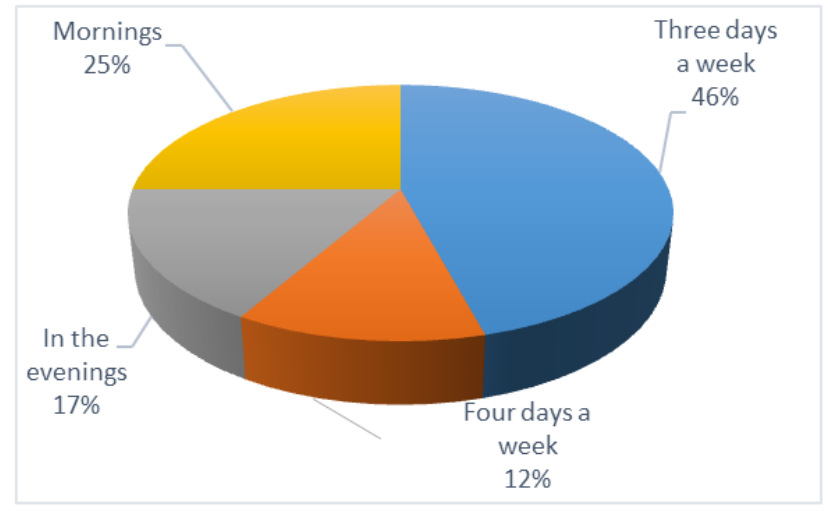

Figure 4. Work rules in individual turnip plots.

\section{Conclusion}

The objective of this paper is to characterize the family structure and family farms in the Kita cotton zone using primary data from the interuniversity project Target collected in 2008. The interest of the choice of the theme lies in the land pressure leading to the presence of turnips and the migratory flow of producers coming mainly from the cotton zone of South Mali to conquer arable land in the Kita circle.

The results show that in the Kita area, there are three types of families, namely the extended family, the mixed family and the nuclear family. This family typology is strongly linked to the organization of the farm. In addition, family breakups in the zone are moderate because in $91.62 \%$ of cases, family members continue to live together under the authority of a main head of household. There are two main types of farms, namely collective and individual farms. Analyses show that the majority of collective plots (86.43\%) were inherited upon the death of the father or former head of the family. Of these collective plots, the head of the family owns $94.97 \%$. The practice of individual farms is a growing phenomenon, $96.89 \%$ of the members living in the concessions have individual farms granted by the head of the family, thus demonstrating the local character of the land lending market. Following the example of the cotton zone in southern Mali (Sikasso, Koutiala, San, etc.), land transactions in the Kita zone are still very low (7.54\% of collective plots), with no cases of land sales, purchases or pledges. They are clearly dominated by informal transactions. In other words, custom continues to govern access to land. It is the relative availability of land that is at the root of the low activity of local land markets, whether it is the market for land loans or leases or, even more so, the market for buying and selling land. In short, land lending transactions are part of a traditional solidarity logic and not a land rental market logic as we know it in advanced countries. 


\section{References}

[1] Bélières, J-F., Bosc, P-M., Faure, G., Fournier, S., Losch, B. (2002). "Quel avenir pour les agricultures familiales d'Afrique de l'Ouest dans un contexte libéralisé", IIED, Dossier $\mathrm{n}^{\circ} 113$, octobre, $46 \mathrm{p}$.

[2] Bélières, J-F., Bonnal, P., Bosc, P-M., Losch, B., Marzin, J. \& Sourisseau, J-M. (2014). "Les agricultures familiales dans le monde: définitions, contributions et politiques publiques", A Savoir 28, octobre, $200 \mathrm{p}$.

[3] Bélières, J-F. (2013). "Agriculture familiale et politiques publiques: étude de cas Mali", Contrat $\mathrm{n}^{\circ} \mathrm{AFD} / \mathrm{STR} / \mathrm{RCH} / \mathrm{REC} / 2012-\mathrm{MCT}-001$ entre l'AFD et le Cirad. 27 p.

[4] Benoit-catin, M. \& Faye, J. (1982). "L'exploitation agricole familiale en Afrique Soudano-sahélienne”, Paris, PUF, 1982.

[5] Brasselle, A-S., Gaspart, F. \& Platteau, J-P. (2002). "Land tenure security and investment incentives: puzzling evidence from Burkina Faso", Journal of Development Economics, Elsevier, vol. 67 (2), pages 373-418, April.

[6] Diao, F. D. (2003). "Typologie des exploitations agricoles de la zone cotonnière sénégalaise: affinement du modèle de la SODEFITEX". Mémoire de fin d'études ENSA Thiès Sénégal. Février, $73 \mathrm{p}$.

[7] FAO (2013). "La situation mondiale de l'alimentation et de l'agriculture: Mettre les systèmes alimentaires au service d'une meilleure nutrition", Rome, 2013. www.fao.org/publications/sofa/fr/.

[8] FAO (2014). "La situation mondiale de l'alimentation et de l'agriculture: ouvrir l'agriculture familiale à l'innovation", Rome, 2015. www.fao.org/publications/sofa/fr/.

[9] França, C. G., Del Grossi, M. E. et Marques, V. P. M. A. (2009). "O censo Agropecuário 2006: e a Agricultura Familiar no Brasil", Brasilia, MDA: 97p.

[10] Gavian, S. and Fafchamps, M. (1996). "Land Tenure and Allocative Efficiency in Niger", American Journal of Agricultural Economics, vol. 78, issue 2, 460-471.

[11] IBGE (2009). "Censo Agropecuário 2006, Agricultura Familiar, primeiros resultados: Brasil, grandes regiões $e$ estado de Federação". Rio de Janeiro, IBGE: 265p.

[12] Kanouté, A. (2003). "Etude comparative des stratégies de couverture de besoins céréaliers dans les exploitations familiales de la zone cotonnière sénégalaise", Mémoire de fin d'études, ENSA Thiès, Février, 53 p.

[13] Kleene, P. (1976). "Notion d'exploitation agricole et modernisation en milieu Wolof Saloum (Sénégal)", L'Agronomie Tropicale, 31 (1): 63-82.

[14] Minot, N., Kherallah, M., Soulé, B. G. et Berry, P. (2001). "Impact des réformes agricoles sur les petits agriculteurs au Bénin ", Résultats des Enquêtes des Petits Agriculteurs, des Communautés et des Groupements Villageois, Vol. 1, IFPRI, Washington DC., 299 p.

[15] Orsini J. P. G., Lhoste, P., Bouchier, A., Faye, A. and Niang, L. (1985). "Une typologie d'exploitations agropastorales au Sine Saloum, Sénégal”. Revue Elev. Méd. Vét. Pays tropicaux,
38 (2): $200-210$.

[16] Owusu, J. G. K., Osei, Y. and Baah, F. (2002). "Current Issues in Agriculture in Ghana: The Future of Family Farming”, paper prepared for IIED Sahel, Dakar, Sénégal.

[17] Parnaudeau, J., (2008). "Pluriactivité, logiques familiales et durabilité des systèmes de production agricole: Analysediagnostic des systèmes d'activités dans la zone Intersalar (Altiplan bolivien)", Série «Master of Science» $\mathrm{n}^{\circ} 90$ de CIHEAM-IAMM, $222 \mathrm{p}$.

[18] Platteau, J. P. \& Guirkinger, C. (2009). "Le foncier: facteur d'efficience ou d'équité dans la vieille zone cotonnière du sud Mali-Aspects relatifs à la migration", Centre de Recherche en Economie du Développement (CRED), Département d'Economie, Université de Namur, Belgique. Convention d'étude RCH 066-2006.

[19] RGA, (2004), "Campagne agricole 2004: Résultats principaux", Ministère de l'agriculture, Ministère de l'Elevage et de la Pêche, Ministère du Plan de l'Aménagement du Territoire.

[20] Sall, M. (2016). "Les exploitations agricoles familiales face aux risques agricoles et climatiques: stratégies développées et assurances agricoles", Thèse de Doctorat/ Economies et finances, Université Toulouse le Mirail - Toulouse II, 2015, $279 \mathrm{P}$

[21] Samaké, A., Bélières, J-P., Koné, B. et Dembélé, U. (2011). "Un observatoire des exploitations agricoles du Mail: Etude de conception réalisée dans le cadre du projet PAPAM", CIRAD/ART.Dev, IER/Ecofil, CRRA.

[22] Sarr, D., Thiam, A. \& Garin, P. (1987). "Description d'une Typologie de Structure des Exploitations dans la communauté rurale de Kaymor (Sud région de Kaolack)", ISRA, Mai, 18 p.

[23] Soukaradji, B., Abdou, A., Lawal, S., Aboubacar, I., Mahamane, A. \& Saadou, M. (2017). "Typologie des exploitations agricoles familiales: cas de la périphérie de la forêt de protégée de Baban Rafi du Niger", Int. J. Biol. Chem. Sci. $11 \quad$ (3): 1096-1112, June, DOI: https://dx.doi.org/10.4314/ijbcs.v11i3.14.

[24] Tchayanov, A. V. (1990). "L'organisation de l'économie paysanne", in Population (French Edition) 45 (6): 1112, November, with 4 Reads DOI: 10.2307/1533574.

[25] Tchayanov, A. V. (1972). "Pour une théorie des systèmes économiques non capitaliste", Analyse et prévision, 13, pp. 19-51.

[26] Toulmin, C. and Guèye, B. (2003). "Transformation de l'agriculture ouest-africaine et rôle des exploitations familiales", IIED, dossier $\mathrm{n}^{\circ} 123$, décembre, $106 \mathrm{p}$.

[27] Zoundi, S. J., Hitimana, L. et Hussein, K. (2005). “Économie familiale et innovation agricole en Afrique de l'Ouest: vers de nouveaux partenariats", Document de synthèse, Club du Sahel et de L'Afrique de l'Ouest, OCDE, mars, 106 p.

[28] Zoundi, S. J. et Hitimana, L. (2003). "Défis de l'accès des exploitations familiales aux innovations agricoles en Afrique de l'Ouest: implications institutionnelles et politiques", Club du Sahel et de L'Afrique de l'Ouest, OCDE, Paris, 15 p.

[29] Dembele, B., Bett, H. K., Mutai, M. and Le Bars, M. (2017). "Dynamics and adaptation of agricultural farming systems in the boost of cotton cropping in southern Mali", African Journal of Agricultural Research, Vol. 12 (18), pp. 1552-1569, 4 May, 2017. 
[30] Guirguissou, M. A., and Anke, N. (2020). "Responses of Rural Households to the Cotton Crisis in Benin", Sustainability 2020, 12, 4207; doi: 10.3390/su12104207, www.mdpi.com/journal/sustainability. 